The Tocqueville Review/La Revue Tocqueville, Vol. XXXVII, n² 2 - 2016

\title{
REPUBLICANISM AND PROPERTY-OWNING DEMOCRACY: HOW ARE THEY CONNECTED?
}

Stuart WHITE

\section{INTRODUCTION}

Recent years have seen a growth of interest in republicanism in academic political theory (Sandel, 1996; Pettit, 1997, 2012; Skinner, 1998; Honohan, 2002). There has also been a more modest growth of interest in "Property-Owning Democracy" (POD) as a form of economic organization, as advocated by John Rawls (Rawls, 1999). A POD is a market economy, with a significant role for private ownership of the means of production, but in which public authority is used to sustain an egalitarian distribution of productive assets so that market outcomes are more equal than is typical of a capitalist society. The categorisation of Rawls's theory as "liberal", combined with the tendency to see "liberalism" and "republicanism" as rival, even opposing schools of thought, might lead one to think that republicanism and POD stand in some kind of rival or antagonistic relationship. There are, however, strong reasons for seeing them as mutually supportive. In this paper I shall explore how POD arguably supports republicanism as a political ideal, and how republicanism also arguably supports POD as an economic ideal. By extension, I shall suggest that liberalism — or, at least, a Rawlsian liberalism—and republicanism are more appropriately seen as mutually supportive than in opposition (see also Audard, 2007; Thomas, 2016).

We begin in section 1 with some opening definitions of republicanism and POD. Republicanism, I argue, is helpfully broken down into (a) a conception of political legitimacy; (b) a conception of liberty; and (c) a conception of citizenship and politics. In sections 2 
and 3 I then set out two ways in which POD supports republicanism. Section 2 discusses how POD supports republican legitimacy, in particular through its support for the value of political equality. I connect this argument to Rawls's concerns about oligarchy and to his own case for POD. Section 3 discusses how POD supports a concern to secure republican liberty (as "non-domination"). Sections 4 and 5 then consider how republicanism might support POD. Section 4 sketches an argument I have developed elsewhere at greater length that a specifically republican form of citizenship is important to the stability of POD (White, 2012). Left to itself, POD might well have a tendency to generate "individualism" in Alexis de Tocqueville's sense of the term, implying a withdrawal from civic engagement and a consequent erosion of citizens' support for the institutions that maintain a POD. A Tocquevillian response to this problem is to foster a republican practice of citizenship that counters "individualism" and encourages civic engagement and a concern for the wider public good. While section 4 discusses a potential problem of stability for POD once established, section 5 considers the possible contribution of republican politics to establishing a POD in the first place. The most contemporary section of the paper, it discusses how a specifically republican approach to politics, focused on the constitution-defining role of "We the people", might be necessary or helpful in pushing back against the 'oligarchic shift' that many capitalist democracies, such asin the Euro-Atlantic region, have experienced in recent years. In this way, a republican politics can create conditions more favourable to the establishment of POD.

Section 6 concludes with a brief discussion of the wider theoretical implications of the discussion, focusing in particular on the relationship between liberalism and republicanism.

\section{I - DEFINING PROPERTY-OWNING DEMOCRACY AND REPUBLICANISM}

Let us begin, therefore, by defining what we mean by POD and republicanism. As a term POD originates in UK politics, being initially adopted by Conservatives in the early/mid-twentieth century as a way of describing their proposed alternative to socialism (Jackson, 2012, 36-40). In the 1950s and 1960s, "Revisionists" in the Labour Party in the UK began to develop ideas about how economic equality could be advanced by changes to the distribution of productive assets and they picked up on the term, in effect contesting 
its Conservative use (Jackson, 2012, 40-44). This is the context in which the economist James Meade used the term in his influential book, Efficiency, Equality, and the Ownership of Property (Meade, 1964). Here Meade distinguishes four ways in which government can promote economic equality. First, it can use taxation and public expenditure (The Welfare State). Second, it can support trade unions to maintain wages (The Trade Union State). Meade argued that, in the UK of the 1960s, these two approaches needed complementing by two further approaches. One was to take public ownership of capital so that the return on capital was available for distribution to the citizenry as a whole (The Socialist State). The idea was not that the state should itself manage or control businesses. Rather, it should, in Meade's view, acquire a stake in businesses across the economy and thereby share in the rise in capital value as the businesses grew and in the returns on this capital. Additionally, the state could act to promote a wider dispersion of privately-held wealth, e.g., through reforms to the structure of inheritance tax. This focus on shaping the private distribution of assets, with an underlying egalitarian ambition, is referred to by Meade under the heading of "Property-Owning Democracy".

Meade's discussion was an important reference point for John Rawls. In his $A$ Theory of Justice, first published in 1971, Rawls argues that the principles of social justice are not satisfied by a free-market capitalist system or even by "welfare-state capitalism". Justice requires either a system in which the means of production are publicly owned, while production is coordinated through the market ("liberal socialism"); or else a system in which the distribution of productive assets, including "human capital", is purposively shaped to limit inequality in the ownership of these assets. This is "property-owning democracy" (Rawls, 1999, xiv-xvi, 239-251). The basic idea is that social justice requires more than corrective tax-transfers to limit the effects of class inequality in a capitalist economy. Rather, it requires the abolition of the capitalist economy itself, in the sense of a market economy with private ownership of the means of production and a strong profile of unequal asset ownership. In place of a capitalist society with a stark division between workers and capitalists, justice requires a market economy in which productive assets are distributed so that the distinction between workers and capitalists is blurred. Ideally, the vast majority of citizens would be both in the sense of 
getting income from the sale of labour-power and from capital. Roughly in line with Rawls's discussion, let us define a POD for purposes of this paper as follows:

Property-owning democracy (POD): An economic system which features (a) large-scale use of the market as an allocative mechanism; (b) large-scale private ownership of the means of production; (c) institutions to limit significantly inequality in private ownership of the means of production and human capital; and (d) a non-trivial public sector, particularly to help with limiting inequality in human capital.

At the institutional and policy level, POD is likely to involve some form of taxation on wealth inheritances (Rawls, 1999, 245-246). It is also compatible with, and arguably requires, the idea of a universal capital grant: a scheme under which each citizen would receive a substantial basic endowment of wealth in early adulthood as of right (Ackerman and Alstott, 1999; White, 2015). Although Rawls does note the possibility of "hybrids" of liberal socialism and POD, he presents them as discrete alternatives (Rawls 1999, 240-242). This contrasts somewhat with Meade's presentation in Efficiency, Equality, and the Ownership of Property. Certainly, in his later work, Meade offers a model of a (more) egalitarian market economy that integrates what Rawls terms "liberal socialism" and POD. In this hybrid, which Meade refers to as "Agathotopia" (the good place), the community owns a sizeable share of productive assets and distributes a "social dividend" to citizens as a share-out of the return on these assets (Meade, 1989). Thus, citizens would derive income from their own work, where earning power is shaped by universal access to quality education; from their own capital, where the distribution of private capital is shaped by policies such as inheritance tax (and, we might add, universal capital grant schemes); and from the social dividend payment which represents their share in the return on the community's public investment fund. In the discussion below, it will help to keep in mind not only POD as defined above but also this "Agathotopian" model or what we may here term extended POD.

If this is how we define POD, what about republicanism? I propose here to define republicanism in terms of specific conceptions of political legitimacy; of liberty; and of citizenship and (the doing of) politics. A political view is more or less republican according to how far it accepts the republican conceptions of legitimacy, liberty and citizenship and politics (as elaborated below). In an ecumenical spirit, 
I leave open here the question of how the three conceptions might be understood in relation to one another. I propose that we define republican conceptions of these three sets of ideas as follows.

Republican conception of legitimacy: a political system is legitimate, such that authority-holders have the right to issue commands, to the extent that (a) laws and policies are made through a genuinely democratic process and (b) laws and policies reflect collective judgments of the common good.

Republican conception of liberty: an individual is free when he or she has the status of non-domination, i.e., is not subject to another's power of arbitrary interference.

Republican conception of citizenship and politics: citizenship is not only a status of holding rights but a practice that involves active participation in political life, animated by a commitment to the common good; politics should give democratic expression to this conception of citizenship.

The republican conception of legitimacy has roots in Jean-Jacques Rousseau's The Social Contract (Rousseau, 1994; Cohen, 2009c). It is an attempt to capture what is of value in Rousseau's claim that legitimacy is tied to the sovereignty of the 'general will'. I take from this the idea that legitimate law-making must be sufficiently sensitive to the views and demands of equal citizens - that it comes equally from all and, in this respect, is genuinely democratic. At the same time, I take the idea that a legitimate law-making process is one that systematically encourages citizen-legislators to frame proposals that serve the shared interests of citizens, conceived as equals. In this respect, law-making must be oriented to the good of all, to their common good. Thus, equal opportunity for political influence is necessary for legitimacy but not sufficient. It must be complemented by practices through which citizens search for their common good. In contemporary political theory, this latter idea is often elaborated using the notion of "deliberative democracy", where "deliberation" refers to a form of civic discussion and argument in which citizens offer reasons for legislative proposals that are suitably linked to considerations of the common good (Cohen, 2009a; Freeman, 2000; Young, 2001).

Let us now turn to the second republican conception, the conception of liberty. Philip Pettit has recently argued that republicanism is distinguished by a particular conception of liberty, liberty as "non-domination" (Pettit, 1997, 2012; see also Skinner, 1998). In his Discourse on the Origins of Inequality, Rousseau says that the 
worst thing that can happen in human affairs is to find oneself living at the mercy of another (Rousseau, 1984, 125). Roughly speaking, freedom as non-domination is the status of not living at another's mercy. As Pettit describes it, it is the status of not being subject to another's power to interfere arbitrarily in one's choices. Skinner elaborates the closely related "neo-Roman" conception of liberty as the status of not being dependent on another's good will. Both contrast this way of approaching liberty to the idea that liberty consists simply in the absence of actual interference: even if nobody is actually interfering with my choices, their power to do so, at their discretion, if they have such a power, casts a shadow over my choices that undermines my freedom. Note that one can accept that liberty in this sense is very important, as I do here, without also claiming that this is the only significant kind of liberty or claiming that the notion of freedom as non-domination is absent from liberal thought.

Finally, turning very briefly to our third republican conception, republicanism is often associated with a particular view of citizenship and with a related, normative view of politics (Nabulsi, 2008). The citizen is appropriately "active" and her activity is centred on political participation, and guided by a commitment to the common good. This model of citizenship, as a virtue-centred practice, has application in the well-ordered republic, but also has application more generally, including in the struggle to create and develop the republic (Nabulsi, 2008; Gourevitch, 2015, 138-173).

\section{II - FIRST CONNECTION: POD SUPPORTS REPUBLICAN LEGITIMACY}

The first connection between POD and republicanism we shall discuss concerns the way POD arguably supports the republican conception of legitimacy. The basic argument can be set out as follows.

The political equality argument:

(1) Republican legitimacy requires that law and policy is made through a genuinely democratic process.

(2) A genuinely democratic process requires political equality: equality of opportunity for political influence.

(3) Equality of opportunity for political influence is undermined by substantial inequality in the ownership of productive assets.

(4) POD prevents substantial inequality in the ownership of productive assets. 
Therefore:

(5) POD helps to maintain equality of opportunity for political influence.

Therefore:

(6) POD helps to maintain a genuine democratic process.

Therefore:

(7) POD helps to maintain republican legitimacy.

The central concept in the argument is that of political equality, understood as equality of opportunity for political influence (Cohen, 2009b). As explained by Joshua Cohen, equality of opportunity for political influence does not mean that all citizens do in fact have equal influence in law- and policy-making. But it does mean that any inequalities in influence must reflect choices about how far to get involved in political decision-making, and in personal abilities, rather than inequality in the resources that citizens have the opportunity to bring to bear in the political process. One important resource that people can bring to bear in the political process of course is money. In many contemporary Euro-Atlantic polities, candidates for political office have a strong need for funds to finance their campaigns. Those with more wealth are in a better position to offer these funds and, in this way, to exert influence over the platforms and preferences of politicians (Lessig, 2015). The wealthy are also more able to offer other kinds of material incentive to politicians. They can also exert influence through the media and various interventions to shape the flow of ideas (e.g., through the funding of think-tanks).

POD acts directly on the background distribution of wealth, however, preventing the large-scale, unequal inheritance of wealth across the generations, and ensuring (or at least promoting) a basic endowment of wealth for all citizens. In this way, it directly limits the inequality of wealth that is one important source of inequality of opportunity for political influence. By helping to protect equality in opportunity for political influence it thereby helps maintain a genuinely democratic political process, which is one key condition for republican political legitimacy.

Rawls's argument for POD appeals in part to its alleged connection with political equality. Rawls is very clear on the threat which wealth inequality poses to genuine democracy: 
Historically one of the main defects of constitutional government has been the failure to insure the fair value of political liberty. The necessary corrective steps have not been taken, indeed, they never seem to have been seriously entertained. Disparities in the distribution of property and wealth that far exceed what is compatible with political equality have generally been tolerated by the legal system. Public resources have not been devoted to maintaining the institutions required for the fair value of political liberty. Essentially the fault lies in the fact that the democratic political process is at best a regulated rivalry; it does not even in theory have the desirable properties that price theory ascribes to truly competitive markets. Moreover, the effects of injustices in the political system are much more grave and long lasting than market imperfections. Political power rapidly accumulates and becomes unequal; and making use of the coercive apparatus of the state and its law, those who gain the advantage can often assure themselves of a favored position. Thus inequities in the economic and social system may soon undermine whatever political equality might have existed under fortunate historical conditions. Universal suffrage is an insufficient counterpoise; for when parties and elections are financed not by public funds but by private contributions, the political forum is so constrained by the wishes of the dominant interests that the basic measures needed to establish just constitutional rule are seldom presented. (Rawls, 1999, 198-199)

One key reason why welfare-state capitalism is not sufficient for social justice, in Rawls's view, is that it allows for such inequalities of wealth which in turn enable the wealthy to control the economy and "political life itself". POD (like liberal socialism) acts on the background distribution of wealth to prevent this (Rawls, 1999, xivxv, 245-246; Rawls, 2001, 139).

It seems clear that in this respect POD is helpful to political equality and, thus, to republican legitimacy. Critics have wondered, however, both about its necessity and sufficiency to political equality and, thus, to republican legitimacy. On the one hand, critics have argued that the problem of "money in politics" can be addressed through laws that directly target campaign finance and the like, removing the need for reduction of underlying wealth inequality. This concern, they argue, consequently does not offer a strong justification for POD as against, say, welfare-state capitalism (O’Neill, 2012, 8184). What this argument perhaps underestimates, however, is the extent to which substantial wealth inequality puts political equality under permanent siege. Specific, targeted laws might help to bolster the defences and manage the threat. But the stability of the democratic polity is surely enhanced if we can lift the state of siege 
itself, so to speak; this points in the direction of POD—or at least of some system that goes beyond welfare-state capitalism in addressing background wealth inequality.

A somewhat different criticism is that even if POD reduces wealth inequality there arguably remains a threat to democracy in that wealth-holders might still have undue political influence by refusing to invest if particular policies are enacted. The democratic state remains, in Marxist terms, "structurally dependent" on capital (Cohen, 1989, 28; White, 2012). This suggests that the democratic state must itself have control over investment, and this moves us away from POD and in the direction of a socialist economy. Admittedly, in the hypothetical case of POD we are imagining, the underlying issue is not really about political equality as, by definition in a POD, wealth is distributed in an egalitarian fashion. But there might still be a threat to republican legitimacy. Even if wealth is distributed quite equally, some policies that citizens would support as voters might be rendered unfeasible by the private investment decisions they can be expected to make in response as wealth-holders. This might be thought to limit the effective sovereignty of the democratic citizen body (White, 2012). This challenge raises issues that I lack space to consider here. But insofar as it is valid, it does point to a limit to POD as a way of supporting republican legitimacy, albeit one that could perhaps be mitigated in a form of Meade-style extended POD that includes a liberal socialist element. A full analysis would also need to consider whether a socialist alternative to POD might not also carry risks to democracy. How would public control over investment work in practice? How would it itself respect political equality? To sum up, POD almost certainly represents an advance in terms of political equality (and, thus, republican legitimacy) relative to contemporary capitalism; whether it is optimal in this respect is a more disputable matter.

\section{III - SECOND CONNECTION: POD SUPPORTS REPUBLICAN LIBERTY}

A second important connection between POD and republicanism concerns the potential contribution of POD to securing republican liberty. The basic argument here may be set out as follows. 
The liberty argument:

(1) Liberty as non-domination is supported by economic independence: by having an income that is not dependent on the discretion of another such as an employer, spouse, or state bureaucrat.

(2) Economic independence is supported by owning wealth.

(3) POD ensures that wealth is distributed across all citizens.

Therefore:

(4) POD supports economic independence across all citizens.

Therefore:

(5) POD supports enjoyment of liberty as non-domination by all citizens.

The first step in this argument has been developed in recent work by Daniel Raventós and David Casassas (Raventós, 2007; Casassas, 2007). If one lacks access to the goods and services necessary to meet basic needs, then others, who can give one access to these resources, can have an important source of power over you. They can make your access to the goods and services dependent on conforming to their will. If you desperately need the resources, and have no rival source for them, then you are in a position where you have little option but to conform to their will. Consequently, you are in a position where you experience domination: you are subject to another's power to interfere in your choices at their will. To be dominated, is, on the republican conception of liberty, to be unfree. To lack economic independence, therefore, is to be unfree; or, at least, to be vulnerable to unfreedom.

This insight has played a significant role in working-class opposition to capitalism. Consider, as an example, the following passage written by striking cotton-spinners in Manchester in the early nineteenth-century:

The master spinners are a class of men unlike all other master tradesmen in the kingdom. They are ignorant, proud, and tyrannical. What then must be the men or rather beings who are the instruments of such masters? Why, they have been for a series of years, with their wives and their families, patience itself - bondmen and bondwomen to their cruel taskmasters. It is in vain to insult our common understandings with the observation that such men are free; that the law protects the rich and poor alike, and that a spinner can leave his master if he does not like his 
wages. True; so he can; but where must he go? Why to another, to be sure. Well: he goes; he is asked where did you work last: 'did he discharge you?' No; we could not agree about wages. Well I shall not employ you nor anyone who leaves his master in that manner.... What then is the man to do? If he goes to the parish, that grave of all independence, he is there told - We shall not relieve you; if you dispute with your master, and don't support your family, we will send you to prison; so that the man is bound, by a combination of circumstances, to submit to his master. (Thompson, 1963, 179)

The basic claim is clear: as workers we have no choice in effect but to agree to the terms of employment presented to us by our respective employers and this makes us subject to their will, placed in a position of submission to a "master".

The second step in the liberty argument for POD is that ownership of wealth-of assets that provide an income-establishes a degree of economic independence and therefore diminishes one's vulnerability to domination. If workers have some wealth, then, as Meade put it, they can "snap their fingers" at an employer and walk out because they know they can live for a time on their own wealth (Meade, 1964, 38-39, quoted in Ackerman and Alstott, 1999, 25-26). Obviously this effect is stronger the more wealth one has. But even a modest amount can arguably give the individual a crucial degree of "independence", enabling them to search more widely for job offers (or other economic opportunities) and reducing the pressure to scramble into a specific job and conform to the employer's will. Thus, insofar as POD manages to spread wealth ownership across all adult citizens it helps to promote liberty as non-domination for them. This is why there is a deep connection between the commitment to securing liberty as non-domination and universalising property in some form.

Again, however, while POD seems clearly helpful to republican liberty in the manner suggested, critics might question whether it is necessary or optimal in this regard. Raventós and Casassas, for example, both argue that economic independence, and thus republican liberty, is best served by a universal basic income payment from the state: each citizen receives an income from the state without any test of willingness to work or of means. A basic income in this sense can surely provide economic independence just as much as ownership of wealth. Indeed, in one respect at least, the basic income approach seems better. Wealth, after all, is always something the 
individual can lose, e.g., through a misguided investment. If they do, then their economic independence is also lost, at least temporarily, and their liberty is at risk. By comparison, a basic income, paid regularly, and provided it cannot be converted into a capital sum, offers a more secure basis for economic independence. Thus, what really serves republican liberty, it might be said, is not POD but a scheme of (non-mortgageable) universal basic income (Raventós, 2007; Casassas, 2007).

In response, we should note that what I have termed extended POD actually involves both a wide dispersion of wealth and a universal basic income: the basic income is the social dividend that each citizen receives as their share of the return on the state's investment fund. This can of course also be topped up through the tax-transfer system. Still, the critic might argue that even extended POD does not go far enough in this respect. Under extended POD, economic independence is supported by a mix of basic income and dispersed wealth. The latter is still alienable, so would it not be better in principle to have a system in which economic independence depends only on a basic income? To this challenge, I have two responses (for helpful discussion, see also Bidadanure, 2014a, 2014b, 142-170; White, 2015). First, in institutional terms, there is arguably a benefit from having economic independence supported from different directions rather than resting too much on one specific policy. This might make economic independence more protected from the risks of policy change by spreading this risk across different policy instruments. Second, there are intrinsic benefits to citizens holding alienable wealth, e.g., in terms of supporting personally valued investments, which also need to be taken into consideration. If republican liberty is our only concern, perhaps there is a case for basic income alone over the more mixed approach, at least if the former is relatively secure in political terms. But republican liberty isn't, or shouldn't be, our only concern. The opportunity to marshal resources to support a valued personal project, commercial or otherwise, is also important, and we might reasonably view a mixture of basic income and personal wealth holding as striking the most reasonable balance between the interest in republican liberty and this other important interest. If so, then even if an extended POD does not promote republican liberty as much as a system with a higher 
basic income would, it arguably promotes republican liberty to the right extent in an all-things-considered sense.

\section{IV - THIRD CONNECTION: REPUBLICAN CITIZENSHIP SUPPORTS POD}

So far we have focused on how POD supports republican commitments. Let us now consider how republican commitments might support POD. A first connection here relates to the stability of POD once established. The basic argument may be set out as follows (drawing on White, 2012).

The stability argument.

(1) POD creates pressures towards "individualism" (in Tocqueville's sense of the term).

(2) "Individualism" threatens to undermine the sense of justice that is necessary to sustain POD over time.

However:

(3) Pressures towards "individualism" can be countered effectively by institutions that embody a republican conception of citizenship.

\section{Therefore:}

(4) Republican citizenship helps to increase the stability of POD over time.

POD is a market-centred economic system. Although assets are distributed on a relatively equal basis, economic life is still characterised by a degree of competition and differences in reward and success. As I have argued at greater length elsewhere, the image POD conjures up is in some ways similar to what Tocqueville claimed to see in the democracy of the USA in the early nineteenth century. Amongst white men at least, this was a society characterised, in Tocqueville's view, by a relative equality of education and capital (Tocqueville, 2003, 617). It was a society in which no individual could be assured of staying very rich, but in which there was also a realistic possibility of material advance. Tocqueville argues, of course, that a society that is egalitarian or democratic in this way-based on a wide dispersion of productive assets-carries a significant tendency towards individualism: "a calm and considered feeling which persuaded each citizen to cut himself off from his fellows and to withdraw into the circle of his family and friends in such a way that he thus creates a small group of his own and willingly abandons 
society at large to its own devices" (Tocqueville, 2003, 587). Individualism has both an affective and cognitive aspect. Affectively, it involves the withdrawal from the public sphere, and concern for one's fellow citizens, described above. Cognitively, it involves having a diminished, inaccurate sense of one's interdependency with others, a failure to see how one is part of a cooperative social scheme. The cognitive error helps maintain the affective withdrawal.

If Tocqueville is correct in this sociological thesis, then this may have implications for a society which bases its economic life on POD. As noted, POD involves ongoing collective action to sustain an egalitarian distribution of productive assets. This is achieved through public policies such as publicly-funded education, stable rules about the taxation of wealth and inheritances and, perhaps, a scheme of universal capital grants. The stability of POD depends, therefore, on the continuation of these policies. This in turn depends on citizens being willing to continue to vote for and otherwise support these policies. This depends on citizens having what Rawls calls an effective "sense of justice" (Rawls, 1999, 41, 274-275). They must have an appreciation of the principles of social justice and of how policies such as the ones just described work to fulfil them. They must be willing to carry any sacrifices this might imply, e.g., in terms of taxation of wealth transfers within the family. Individualism, however, in the sense outlined above, seems to jeopardise this sense of justice. Consequently, if POD does indeed foster individualism in this sense, it looks as if there is instability at the core of POD. Even if the POD is established, its operation will promote cognitive error and attitudes that are at odds with the sense of justice that is needed over the longrun to sustain POD. POD will be self-undermining in practice.

In Democracy in America, however, Tocqueville argues that the Americans have found a way to counter the risk of individualism. Participation in democratic self-government at the local level pulls citizens out of their private spheres. In the course of engaging with others to address local problems, they are reminded of how their society is in fact a cooperative scheme and they are encouraged to develop concern for how well this scheme is functioning-a concern, in other words, for the welfare of their fellow citizens. As Tocqueville puts it:

As soon as communal affairs are treated as belonging to all, every man realizes that he is not as separate from his fellows as first imagined and 
that it is often vital to help them in order to gain their support... When the public is in charge, every single man feels the value of public goodwill and seeks to court it by attracting the regard and affection of those amongst whom we live.

Many of the emotions which freeze and shatter men's hearts are then forced to withdraw and hide away in the depths of their souls. Pride conceals itself; scorn dares not show its face. Egoism is afraid of itself. (Tocqueville, 2003, 592.)

Thus, Tocqueville claims that the "one effective remedy" to the "evils produced by equality" is "political freedom", by which he means primarily here participation in local self-government (Tocqueville, 2003, 595). In his Considerations on Representative Government, influenced by Tocqueville, John Stuart Mill makes a similar argument, referring to the "moral part of the instruction afforded by the participation of the private citizen, if even rarely, in public functions. He is called upon...to weight interests not his own; to be guided...by another rule than his private partialities; to apply...principles and maxims which have for their reason of existence the common good..." (Mill, 1993, 233). If Tocqueville and Mill are correct in this claim about the morally educative effects of political participation, then we can perhaps see a way in which the potential instability at the core of POD can be addressed. By structuring the state so as to foster a specifically republican form of citizenship, characterised by active participation in political decisionmaking, the state can counter individualism and in this way possibly help sustain the sense of justice that is necessary to maintain POD (White, 2012). In this respect, republican citizenship putatively supports POD.

Clearly, this argument rests on two empirical claims that need further support than I offer here: that POD is subject to a problem of individualism and that institutions that promote republican citizenship are effective in addressing this problem. Moreover, even if these claims are correct, the argument does not show that a republican form of citizenship is strictly necessary to POD, rather than helpful to it. Perhaps there are other institutional responses that can also help to stabilise POD against the risks of individualism, making republican citizenship unnecessary (see Hussain, 2012). Nevertheless, we can say that there are reasonably strong considerations for thinking that the promotion of republican citizenship is supportive of POD's stability. 


\section{V - FOURTH CONNECTION: REPUBLICAN POLITICS SUPPORTS POD}

The argument just set out concerns the stability of POD once established. But POD is not yet established in any nation. Establishing a POD is, moreover, a major political challenge. Because it involves a significant change in property and power relations relative to contemporary capitalism, creating a POD is always likely to be a major challenge. But has the challenge increased? Colin Crouch argues that many Euro-Atlantic polities have shifted over the past few decades towards a "post-democratic" state. Over the first half of the twentieth century the labour movement rose in these polities and, through a combination of party political presence and union organization, gradually balanced the power of the rich and business. The post-war "Keynesian welfare state", in its various permutations, was a reflection of this (Crouch, 2004, 4-11). During the past thirty or so years, however, power over policy-making has tipped back towards business interests and the very rich:

Behind this spectacle of the electoral game, politics is really shaped in private by interaction between elected governments and elites that overwhelmingly represent business interests.... while the forms of democracy remain fully in place...politics and government are increasingly slipping back into the control of privileged elites in the manner of pre-democratic times... (Crouch, 2004, 4, 6).

In the USA, important recent studies by Jacob Hacker and Paul Pierson and by Martin Gilens and Benjamin I. Page also point to what one might call an "oligarchic shift" in the way policy-making works (Hacker and Pierson, 2010; Gilens and Page, 2014).

Against the background of this alleged oligarchic shift, the prospects for moves towards POD look even more challenging (at least in the Euro-Atlantic polities). In particular, to advance PODrelated policies in the context of ordinary politics, given the background of the oligarchic shift, looks like a recipe for limited progress, if not outright defeat. To open up even the possibility of significant moves in a POD-like direction it seems necessary to first counter the oligarchic shift itself. This implies less of an immediate focus on ordinary politics and public policy and more of a focus on what one might call constitutional politics, a politics that addresses 
the political system itself and which purposefully seeks reforms to the political system in order to counter the rise of oligarchic power (Hind, 2014; White, forthcoming; see also Ronzoni, 2015).

In connection with this it is interesting to see the emergence in recent years of various kinds of citizen politics that incorporate a critique of the existing political system and a demand for fundamental constitutional reform. Examples include-but are by no means exhausted by - the various "movements of the squares" such as the 15-M movement in Spain and the related Occupy movement in the USA and elsewhere (Gitlin, 2012; Ishkanian, Glasius, and Ali, 2013; Kaldor and Selchow, 2014; White, forthcoming); the movement for constitutional reform in Iceland (Landemore, 2015); and perhaps also the independence movements in Scotland and Catalonia. To varying extents, these initiatives have a strong republican quality in two senses. First, they often seem to embody a strong "tribunate" element. They frequently involve attempts to visibly gather the "people" in an open, public setting and in a way that is presented as in opposition to an elite, e.g., as in the Occupy movement's rhetoric of the $99 \%$ against the $1 \%$. Second, also in their practices of open, public assembly, and in some of the demands for political reform that they articulate, these initiatives express the principle of popular sovereignty. They can be understood as efforts to reawaken a working sense of "We the people" as a prerequisite of a democratic politics of fundamental constitutional reform (Hind, 2014; White, forthcoming).

With this in mind, we can thus perhaps see a fourth connection between republicanism and POD, which we can set out as follows.

The anti-oligarchy argument.

(1) Some "capitalist democracies" have experienced an oligarchic shift in recent decades.

(2) Policies to move towards POD are made less feasible by an oligarchic shift in power.

However:

(3) A revival of republican political practices, aimed at democratising reforms of the political system, offers a way of countering an oligarchic shift in power.

Therefore: 
(4) Where an oligarchic shift has occurred, revival of republican political practices, aimed at democratising reforms of the political system, offers a way of increasing the feasibility of policies to move towards POD.

It is of course important to acknowledge the limitations of this argument. For one thing, it is not being claimed that democratising reforms of the political system, reducing the influence of the very rich and of business corporations, will necessarily lead to the adoption of POD-like policies. The claim is only that such reforms remove an obstacle to their adoption. But such policies would still have to win popular support, not least amongst the citizens who have become active in the cause of democratising reform itself. Second, the argument as stated conveniently glosses over the question of just how the revival of republican political practices, as exemplified in the movements of the squares, does lead to actual and significant reforms that diminish oligarchic power. This may be one of their aims. But how is it to be achieved? Sceptics will point out that the highly visible public assemblies and protests of the 15-M movement and Occupy have long since disappeared. The sceptic will argue that they have achieved little and that little is likely to issue from them or similar events in the future.

In response, it is important to take a longer term perspective than that offered by the critic. It may be that the movements of the squares represented the early stages of a political development that will take many more years to work itself out. It would be rash to assume the eventual success of such a movement, but also is unduly pessimistic to conclude that its initial failure implies ultimate failure. Here one might note the case of Iceland where the initial movement for constitutional reform was halted in 2012 but which, at time of writing, may shortly resume following new legislative elections in 2016. Nevertheless, the objection points to a key issue that movements of this kind need to address - how to expand the opportunities for such movements to make effective interventions at the level of constitutional politics. There is a "bootstrapping" problem here: How does such a movement intervene effectively to change the underlying constitutional structure, so as to make it easier to make such interventions, before an enabling constitutional reform has been made? 
CONCLUSION: POD, REPUBLICANISM AND THE LIBERAL-REPUBLICAN DEBATE

This paper has set out four ways in which republicanism and POD might be connected. Establishing a POD is at least helpful to republican legitimacy (first connection) and to republican liberty (second connection). It is reasonable, on Tocquevillian grounds, to think that republican citizenship is supportive of the stability of POD (third connection). In addition, a republican politics, affirming popular sovereignty over the constitution and seeking democratic reform, is arguably a precondition for serious policy moves in the direction of POD, at least in Euro-Atlantic polities that have in recent years experienced an oligarchic shift in power (fourth connection).

In closing, I want to draw out some wider implications of the discussion for how we think about the relationship between liberalism and republicanism in political theory. Republican political theorists often define their position in opposition to liberalism, and some liberals are happy to reciprocate. Common to both is the tendency to view liberalism and republicanism as complete, self-contained political theories. An alternative perspective is to see liberal and republican ideas more as modules that form parts of a complete political theory. For example, on the question of what social justice is, one might have a liberal module, based on, say, Rawls's proposed two principles. One might also adopt a liberal module on the question of what kind of economic system secures social justice. POD, as proposed by Rawls, or extended POD as developed in the work of Meade, can also be seen as liberal modules in this sense. At the same time, however, one might adopt republican modules with respect to other ideas, as we have in this paper with respect to what political legitimacy is, what liberty is, and how best to conceive of citizenship and politics. Of course, not every liberal module will be compatible with every republican module. But some might be consistent and even mutually supportive. In the case we have been discussing, for example, the four connections we have explored suggest that liberal modules on justice and economic organization cohere well with republican modules on legitimacy, liberty and citizenship and politics. (Specific combinations might also have an effect on a given module's content as when the republican liberty module leads us to give greater emphasis than we otherwise might to basic income in the POD/expanded POD economic organization module.) Our overall 
political theory might thus have both liberal and republican elements, and be all the stronger for it. Republicanism and liberalism ought not to be seen as complete, self-contained alternatives but as modular toolkits of ideas that we can usefully draw on and combine in building the best political theory we can.

\section{REFERENCES}

Ackerman, Bruce, and Alstott, Anne, The Stakeholder Society, New Haven, Yale University Press, 1999.

Audard, Catherine, John Rawls, Stocksfield, Acumen, 2007.

Bidadanure, Juliana, "Basic Income versus Basic Capital: An Intergenerational Perspective", paper presented at Summer School on Predistribution and Property-Owning Democracy, University of Minho, July 14-18, 2014a.

Bidadanure, Juliana, Treating Young People as Equals: Intergenerational Justice in Theory and Practice, Ph.D thesis, University of York, York, 2014b.

Casassas, David, "Basic Income and the Republican Ideal: Rethinking Material Independence in Contemporary Societies", Basic Income Studies, 2 (2), 2007.

Cohen, Joshua, "The Economic Basis of Deliberative Democracy", Social Philosophy and Policy, 6 (2), 1989, pp. 25-50.

Cohen, Joshua, "Deliberation and Democratic Legitimacy", in Joshua Cohen, Philosophy, Politics, Democracy, Cambridge: MA, Harvard University Press, 2009a, pp. 16-37.

Cohen, Joshua, "Money, Politics, Political Equality", in Joshua Cohen, Philosophy, Politics, Democracy, Cambridge, MA, Harvard University Press, 2009b, pp. 268-302.

Cohen, Joshua, Rousseau: A Free Community of Equals, Oxford, Oxford University Press, 2009c.

Crouch, Colin, Post-Democracy, Cambridge, Polity, 2004.

Freeman, Samuel, "Deliberative Democracy: A Sympathetic Comment", Philosophy and Public Affairs, 29 (4), 2000, pp. 371-418.

Gilens, Martin, and Page, Benjamin I., "Testing Theories of American Politics: Elites, Interest Groups, and Average Citizens", Perspectives on Politics, 12, 2014, pp. 564-581. 
Gitlin, Todd, Occupy Nation: The Roots, the Spirit, and the Promise of Occupy W all Street, New York, Harper Collins, 2012.

Gourevitch, Alex, From Slavery to the Cooperative Commonwealth: Labor and Republican Liberty in the Nineteenth Century, Cambridge, Cambridge University Press, 2015.

Hacker, Jacob S., and Pierson, Paul, Winner-Take-All-Politics: How Washington Made the Rich Richer - and Turned its Back on the Middle Class, New York, Simon and Schuster, 2010.

Hind, Dan, The Magic Kingdom: Property, Monarchy, and the Maximum Republic, London, Zero, 2014.

Honohan, Iseult, Civic Republicanism, London, Routledge, 2002.

Hussain, Waheed, "Nurturing the Sense of Justice: The Rawlsian Argument for Democratic Corporatism”, in Martin O’Neill and Thad Williamson, eds., Property-Owning Democracy, pp.180-200.

Ishkanian, Armine, Glasius, Marlies, and Ali, Irum S., Reclaiming Democracy in the Square: Interpreting the Movements of 2011-12, Department of Social Policy, London School of Economics, http://eprints.lse.ac.uk/53474/, 2013.

Jackson, Ben, "Property-Owning Democracy: A Short History", in Martin O'Neill and Thad Williamson, eds., Property-Owning Democracy, pp. 33-52.

Kaldor, Mary, and Selchow, Sabine, 'The 'Bubbling Up' of Subterranean Politics in Europe", Journal of Civil Society, 9, 2014, pp. 78-99.

Landemore, Hélène, "Inclusive Constitution-Making: the Icelandic Experiment”, Journal of Political Philosophy, 23, 2015, pp. 166-191.

Lessig, Lawrence, Republic, Lost: Version 2.0: How Money Corrupts Congress - and a Plan to Stop It, New York, Twelve, 2015.

Meade, James, Efficiency, Equality, and the Ownership of Property, London, Allen and Unwin, 1964.

Meade, James, Agathotopia: The Economics of Partnership, Aberdeen, University of Aberdeen, 1989.

Mill, John Stuart, "Considerations on Representative Government", in John Stuart Mill, Utilitarianism, On Liberty, Considerations on Representative Government, London, Dent, 1993, pp. 187-428.

Nabulsi, Karma, "Mobilisation, Representation and Republican Movements", Renewal, 16 3/4, 2008, pp. 117-125.

O’Neill, Martin, “Free (and Fair) Markets Without Capitalism: Political Values, Principles of Justice, and Property-Owning Democracy", in Martin O'Neill and Thad Williamson, eds., Property-Owning Democracy, pp. 75-100.

O’Neill, Martin, and Williamson, Thad, eds., Property-Owning Democracy: Rawls and Beyond, Oxford, Wiley-Blackwell, 2012.

Pettit, Philip, Republicanism: A Theory of Freedom and Government, 
Oxford, Oxford University Press, 1997.

Pettit, Philip, On the People's Terms: A Republican Theory of Democracy, Cambridge, Cambridge University Press, 2012.

Raventós, Daniel, Basic Income: The Material Conditions of Freedom, London, Pluto, 2007.

Rawls, John, A Theory of Justice: Revised Edition, Cambridge MA, Harvard University Press, 1999 [1971].

Rawls, John, Justice as Fairness: A Restatement, Cambridge: MA, Harvard University Press, 2001.

Ronzoni, Miriam, "How social democrats may become reluctant radicals: Thomas Piketty's Capital and Wolfgang Streeck's Buying Time", European Journal of Political Theory, 2015, DOI: 10.1177/1474885115601602. Publication link: 37c1d566-8f0c49fd-a201-1e39dec7e351.

Rousseau, Jean-Jacques, translated by Maurice Cranston, A Discourse on Inequality, Harmondsworth, Penguin, 1984 [1755].

Rousseau, Jean-Jacques, translated by Christopher Betts, The Social Contract, Oxford, Oxford University Press, 1994 [1762].

Sandel, Michael, Democracy's Discontent: America in Search of a Public Philosophy, Cambridge: MA, Harvard University Press, 1996.

Skinner, Quentin, Liberty Before Liberalism, Cambridge, Cambridge University Press, 1998.

Tocqueville, Alexis de, trans. Gerald E. Bevan, Democracy in America, Harmondsworth, Penguin, 2003 [1835, 1840].

Thomas, Alan, Republic of Equals: Predistribution and Property-Owning Democracy, Cambridge, Cambridge University Press, 2016.

Thompson, E. P., The Making of the English Working Class, Harmondsworth, Penguin, 1963.

White, Stuart, "Property-Owning Democracy and Republican Citizenship" in Martin O'Neill and Thad Williamson, eds., PropertyOwning Democracy: Rawls and Beyond, Oxford, Wiley-Blackwell, 2012, pp. 129-146.

White, Stuart, "Basic Capital in the Egalitarian Toolkit?", Journal of Applied Philosophy, 32 (4), 2015, pp. 417-431.

White, Stuart, "Horizontalism, Public Assembly, and the Politics of Republican Democracy", in Yiftah Elazar and Genevieve Rousseliere, eds., Republican Democracy, Cambridge, Cambridge University Press, forthcoming.

Young, Iris Marion, Inclusion and Democracy, Oxford, Oxford University Press, 2001. 